\title{
ALTERATION OF AVIAN HEPATIC CYTOCHROME P450 GENE EXPRESSION AND ACTIVITY BY CERTAIN FEED ADDITIVES
}

\author{
Orsolya PALóCz ${ }^{1}$, Géza SzITA² and György CsiKó ${ }^{1 *}$ \\ ${ }^{1}$ Department of Pharmacology and Toxicology and ${ }^{2}$ Department of Food Hygiene, \\ University of Veterinary Medicine, István u. 2, H-1078 Budapest, Hungary
}

(Received 23 April 2019; accepted 31 July 2019)

\begin{abstract}
We investigated the effect of four feed additives, namely $\beta$-glucan, a drinking water acidifier (DWA), a sanguinarine-containing product (SN) and fulvic acid, on hepatic cytochrome P450 (CYP) mRNA expression and CYP enzyme activity in chickens. The test substances were given to the chickens in the recommended dose or in tenfold dose. The administration of $5 \mathrm{mg} / \mathrm{kg}$ body weight (bw) $\beta$ glucan and $0.1 \mathrm{ml} / \mathrm{kg}$ bw DWA for five days decreased the relative gene expression of CYP1A4 and CYP2C23a. The dosing of $50 \mathrm{mg} / \mathrm{kg}$ bw $\beta$-glucan, 5 and $50 \mathrm{mg} / \mathrm{kg}$ bw SN, $1 \mathrm{ml} / \mathrm{kg}$ bw DWA and $250 \mathrm{mg} / \mathrm{kg}$ bw fulvic acid doubled the hepatic CYP1A4 activity. The activity of CYP2C and CYP3A remained unchanged. Avoidance of CYP1A-mediated feed-drug interactions requires accurate dosing of $\beta$-glucan, DWA and fulvic acid. According to our results, no treatment resulted in excessive or less CYP2C and CYP3A protein formation, which reduces the risk of potential feed additive-drug interactions in chickens. However, the administration of feed additive SN containing a plant alkaloid should be avoided concomitantly with CYP1A-metabolised medicines.
\end{abstract}

Key words: Chicken, cytochrome P450 mRNA and enzyme activity, feed additives

Domesticated chickens, as one of the most important food protein sources, should remain healthy and antimicrobial-free during the entire raising period. Feed additives may improve the immunity and feed utilisation of chickens. The effect of these feed additives on drug-metabolising enzymes is unknown, although the flock may need to be treated at any time during the growing period, and it is questionable whether the additives cause any alteration in cytochrome P450 (CYP) enzyme activity, which may modify the therapeutic effect of medicines.

Xenobiotic-metabolising CYPs are known to be expressed primarily in the liver, and the most important CYP isoenzymes belong to the families CYP1-3. The mRNA expression levels of CYPs are in correlation with their enzymatic activity, but the degree of correlation depends on the CYP isoform (Temesvári et

*Corresponding author; E-mail: csiko.gyorgy@univet.hu 
al., 2012). Watanabe et al. (2013) found that CYP2C45 showed the highest basal mRNA expression in chicken liver, and CYP2C23b gene was the most induced gene by phenobarbital followed by CYP2C23a and CYP2C45, although CYP2C23a showed higher enzyme activity compared to CYP2C45 after phenobarbital exposure. The high abundance of CYP2C subfamily in chickens indicates the importance of these enzymes in avian drug metabolism. Several substances are available for use as feed additives or drinking water supplementation in livestock farming. In our study we investigated the effect of $\beta$-glucan, a sanguinarine-containing product (Sangrovit ${ }^{\mathbb{B}}$ ), a drinking water acidifier (Immunofort $\left.^{\circledR}\right)$, and fulvic acid.

The (1-3), (1-6) $\beta$-glucans, the cell wall constituents of fungi, are recognised by mammalian cells as pathogen-associated molecular patterns and thus act as biological response modifiers. The fungal $\beta$-glucans act as broad-spectrum enhancers of host defence mechanisms, positively influencing the immunological response of mammals to bacterial, viral, and fungal infections (Palócz and Csikó, 2014). Sangrovit ${ }^{\circledR}$ is a natural plant-derived (Macleaya cordata) phytogenic feed additive containing many benzophenanthridine alkaloid compounds, the most abundant of which is sanguinarine (Kantas et al., 2015). Dietary supplementation with Sangrovit ${ }^{\circledR}$ significantly improved body weight and feed conversion ratio in broiler chickens (Vieira et al., 2008). Immunofort ${ }^{\circledR}$ is a solution for use in drinking water; it contains volatile fatty acids, amino acids, phosphoric acid, zinc and copper salt complexes. The aqueous solution of the product contains undissociated organic acids, which inhibit the growth of pathogenic microorganisms. Fulvic acid is one of the most active fractions of humic substances which are commonly found in soil. Fulvic acid contains many reactive functional groups, including carboxyls, hydroxyls, carbonyls, phenols, quinones, and semiquinones, which are responsible for its metal-chelating and antioxidant activity (Plaza et al., 2005). Previous studies indicated that fulvic acid formed a film on the mucosal epithelium of the gastrointestinal tract, protected against infections and toxins, and improved the utilisation of nutrients in animal feed (Islam et al., 2005). The chelating ability of humic substances might enhance the intestinal uptake of microelements (Szabó et al., 2017). Dietary supplementation with fulvic acid improved feed efficiency and immunity as well (Chang et al., 2014).

There is a lack of knowledge about how the applied additives act on the pathways of xenobiotic metabolism. If drug therapy becomes necessary in a chicken flock, it is important to know how the administered substances alter the cytochrome P450 expression, leading to interactions with the drugs or their metabolites.

The aim of this study was to investigate the effect of four feed additives, namely $\beta$-glucan, Immunofort ${ }^{\circledR}$ (a drinking water acidifier, DWA), Sangrovit ${ }^{\circledR}$ (a sanguinarine-containing product, $\mathrm{SN}$ ) and fulvic acid on hepatic CYP mRNA expression level and CYP enzyme activity in chickens (Gallus gallus domesticus). 


\section{Materials and methods}

\section{Housing and treatments of chickens}

Forty-five clinically healthy 31-day-old broiler chickens (Ross 308, Herbro Ltd., Hernád, Hungary) were used in this study. The birds were housed in stainless steel cages, five birds per cage, acclimated at $20 \pm 2{ }^{\circ} \mathrm{C}$ on a 12-h light/ 12-h dark schedule. Non-medicated finisher feed $\left(\right.$ Purina $\left.^{\circledR}\right)$ and water were provided ad libitum. The chickens (mean weight $749 \pm 24 \mathrm{~g}$ ) were randomly divided into 9 groups (5 chickens/group) comprising one control group and 8 experimental groups. Four of the 8 experimental groups received the feed additive at the recommended dose, while the other four were given a tenfold dose of the additive. The groups were as follows: groups receiving $\beta$-glucan ( 5 and $50 \mathrm{mg} / \mathrm{kg} \mathrm{bw}$ ), groups receiving the sanguinarine-containing product (SN) (5 and $50 \mathrm{mg} / \mathrm{kg} \mathrm{bw})$, groups receiving the drinking water acidifier (DWA) $(0.1$ and $1 \mathrm{ml} / \mathrm{kg} \mathrm{bw})$, and groups receiving fulvic acid ( 25 and $250 \mathrm{mg} / \mathrm{kg}$ bw). The test substances were freshly dissolved in water daily and were administered via crop tube $(2 \mathrm{ml} / \mathrm{kg} \mathrm{bw})$ to the birds individually for five consecutive days. The controls received the same amount of water via crop tube (placebo). One day after the last treatment day the chickens were euthanised (Euthasol ${ }^{\circledR} 1 \mathrm{ml} / \mathrm{kg}$ bw intracoelomally) and their livers were perfused in situ with physiological saline solution until the blood was drained. Then the livers were collected, shock-frozen in liquid nitrogen and stored at $-80^{\circ} \mathrm{C}$ until further processing.

\section{Feed additives applied}

Baker's yeast $\beta$-glucan (Wellmune WGP ${ }^{\circledR}$, Biothera Company, USA; main

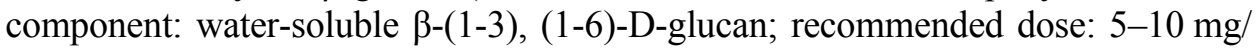
kg body weight).

Sanguinarine-containing product (Sangrovit ${ }^{\circledR}$ WS, Phytobiotics GmbH, Germany; main components: quaternary benzophenanthridine alkaloids and protopine alkaloids; recommended dose: 10-100 g/1000 1 drinking water).

Drinking water acidifier (Immunofort ${ }^{\mathrm{B}}$, Europharmavet Ltd., Hungary; main components: formic acid, propionic acid, phosphoric acid, methionine hydroxy analogue, zinc, copper; recommended dose: 1 1/1000 1 drinking water).

Fulvic acid (Fulvix pulvis ${ }^{\circledR}$, Alpha-Vet Ltd./Organit Ltd., Hungary; main component: fulvic acid: $70 \%$; recommended dose: $250 \mathrm{~g} / 10001$ drinking water) (Palócz et al., 2019).

\section{Microsome separation}

The livers were homogenised with two volumes of ice-cold buffer $(1.15 \%$ $\mathrm{KCl}, 0.1 \mathrm{mM}$ EDTA, $\mathrm{pH}$ 7.4) by a Potter-Elvehjem homogeniser (Schuett Biotec $\mathrm{GmbH}$, Göttingen, Germany). Microsomes were isolated by two-step differential 
ultracentrifugation (Beckman L7-65 Ultracentrifuge, Beckman-Coulter) according to Nebbia et al. (2001). Protein concentrations were measured by Pierce ${ }^{\mathrm{TM}}$ BCA protein assay kit (ThermoFisher Scientific, Waltham, MA, USA).

\section{Quantitative real-time PCR}

The liver samples $(100 \mathrm{mg})$ were homogenised in $1 \mathrm{ml}$ of ice-cold RNAzol RT reagent (Sigma-Aldrich, Steinheim, Germany) by a Potter-Elvehjem homogeniser (Schuett Biotec GmbH, Göttingen, Germany). Total RNA was isolated from the tissue samples according to the manufacturer's instructions. Quantity, A260/ A280 and A260/A230 ratios of the extracted RNA were determined using a NanoDrop ND-1000 Spectrophotometer (Thermo Scientific, Wilmington, USA). Quantitative real-time PCR (qPCR) was performed as described previously (Palócz et al., 2017). The tested genes of interest were the avian cytochrome P450 1A4 (CYP1A4, formerly known as CYP1A1), cytochrome P450 2C23a (CYP2C23a, formerly known as CYP2H1), cytochrome P450 2C45 (CYP2C45) and cytochrome P450 3A37 (CYP3A37). As reference (housekeeping) genes glyceraldehyde 3phosphate dehydrogenase (GAPDH) and $\beta$-actin were selected. The primer sequences are listed in Table 1. The thermal profile for all reactions was $2 \mathrm{~min}$ at $95^{\circ} \mathrm{C}$, then 30 cycles of $10 \mathrm{sec}$ at $95^{\circ} \mathrm{C}, 20 \mathrm{sec}$ at $56^{\circ} \mathrm{C}$, and $10 \mathrm{sec}$ at $72{ }^{\circ} \mathrm{C}$.

\section{Cytochrome P450 activity}

The CYP1A4, CYP3A and CYP2C activities of liver microsome samples were measured using the P450-Glo ${ }^{\mathrm{TM}}$ substrates (Luciferin-CEE, Luciferin-IPA, Luciferin-ME; Promega, Madison, USA) (Palócz et al., 2017). The assays were performed according to the manufacturer's recommendation; the luminogenic substrates and the NADPH regeneration system (Promega, Madison, USA) were added to each 5-fold diluted microsome sample, respectively. After the required time the Luciferin Detection Reagents (Promega, Madison, USA) were added to the mixture and the formed luminescence signal was detected by a luminometer (Victor X2, PerkinElmer, Massachusetts, USA).

\section{Statistical analyses}

Relative gene expression levels of the genes of interest were calculated by the Relative Expression Software Tool (REST) 2009 Software. Statistical analyses were performed by Statistica 13 software (Dell Inc., Round Rock, USA). Differences between means were evaluated by one-way analysis of variance (ANOVA) followed by a post hoc comparison using Dunnett's test. 


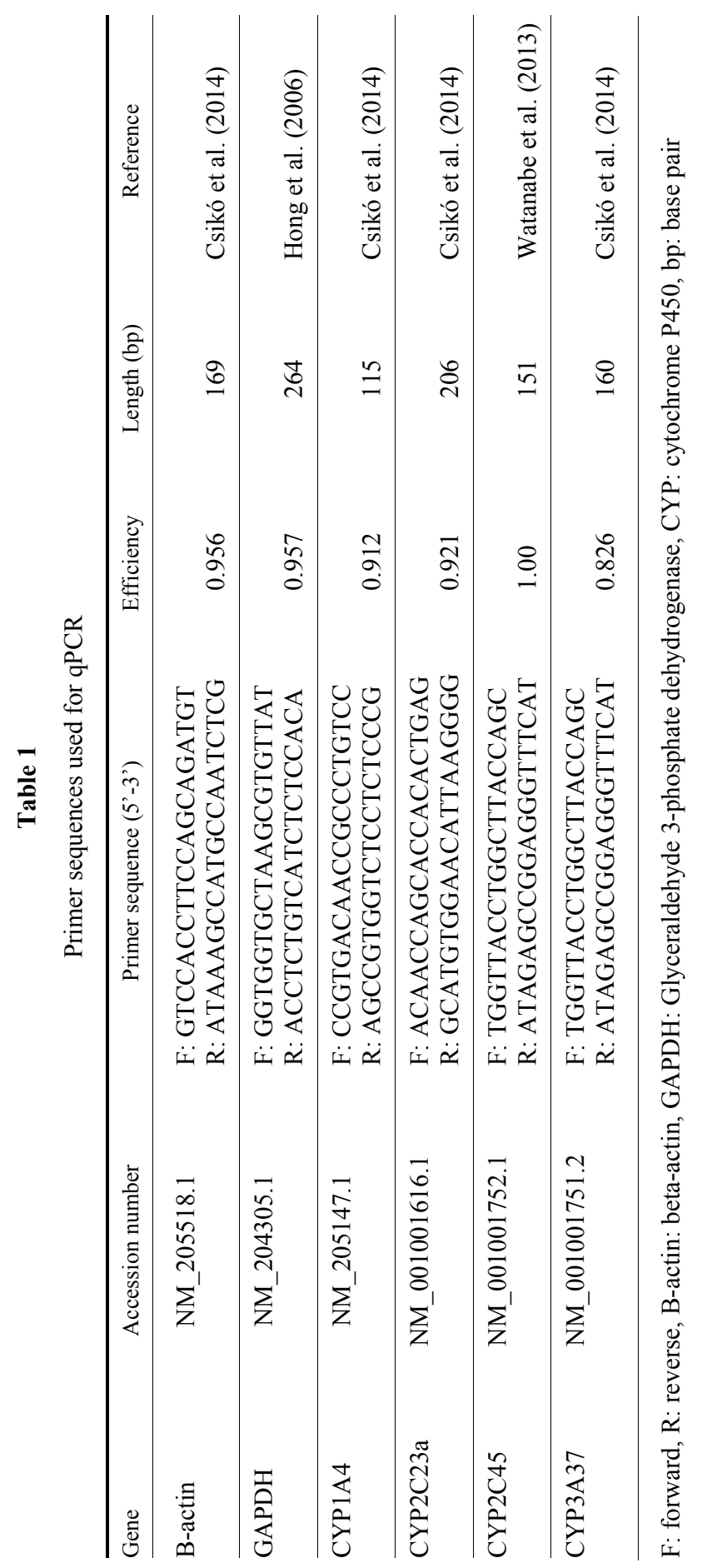




\section{Ethical approval}

The animal trials were conducted according to approved laboratory animal experimentation ethics in conformity with the national and European law, in a manner compatible with the conditions set up by the Guidelines for Ethical Conduct in the Care and Use of Nonhuman Animals in Research. The study was authorised by the Local Institutional Animal Care Committee of the Faculty of Veterinary Science, Szent István University (no. 27/2015).

\section{Results}

The microsome protein concentration was practically equal $(23.17 \pm$ $1.52 \mathrm{mg} / \mathrm{ml}$ ) in each sample. The activities of CYP1A4, CYP2C and CYP3A are shown in Figs 1, 2 and 3, respectively. The administration of $50 \mathrm{mg} / \mathrm{kg}$ bw $\beta$ glucan, $5 \mathrm{mg} / \mathrm{kg}$ bw SN, $50 \mathrm{mg} / \mathrm{kg}$ bw SN, $250 \mathrm{mg} / \mathrm{kg}$ bw fulvic acid and $1 \mathrm{ml} / \mathrm{kg}$ bw DWA to the chickens significantly increased the hepatic CYP1A4 activity $(\mathrm{P}=0.002, \mathrm{P}=0.010, \mathrm{P}=0.015, \mathrm{P}<0.001$ and $\mathrm{P}<0.001$, respectively; Fig. 1$)$. The water-soluble feed additives applied orally for five consecutive days did not alter the activity of chicken hepatic CYP2C and CYP3A enzymes (Figs 2 and 3).

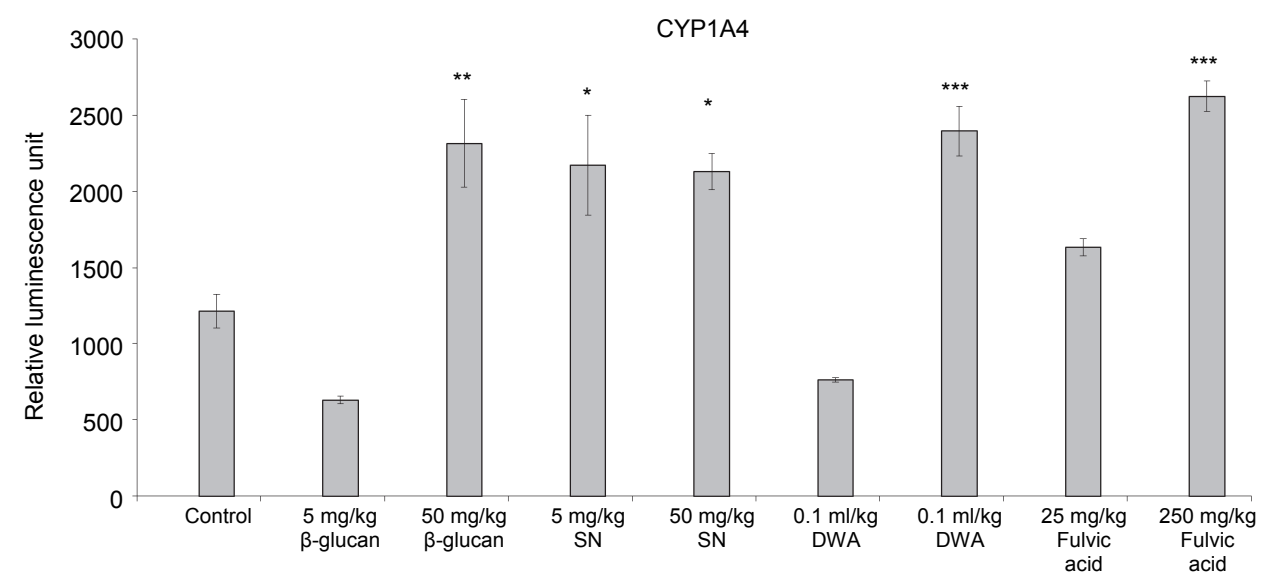

Fig. 1. Changes in cytochrome $\mathrm{P} 4501 \mathrm{~A} 4$ enzyme activity in chicken liver microsomes ( $\mathrm{n}=5 /$ group; ${ }^{*} \mathrm{P}<0.05 ;{ }^{* *} \mathrm{P}<0.01,{ }^{* * *} \mathrm{P}<0.001$; each treatment group compared to control). Data are shown as mean \pm SD. SN - Sanguinarine-containing product, DWA - drinking water acidifier. The chickens were treated orally for 5 days

The results of chicken CYP450 gene expression levels normalised to two housekeeping genes are shown in Fig. 4. Treatment with $5 \mathrm{mg} / \mathrm{kg}$ bw $\beta$-glucan and $0.1 \mathrm{ml} / \mathrm{kg}$ bw DWA downregulated the relative gene expression of CYP1A4 and CYP2C23a. The level of CYP1A4 mRNA decreased to $36 \%, 60 \%$ and $53 \%$ 
after $50 \mathrm{mg} / \mathrm{kg}$ bw $\beta$-glucan, $5 \mathrm{mg} / \mathrm{kg}$ bw SN and $1 \mathrm{ml} / \mathrm{kg}$ bw DWA administration, respectively. Furthermore, the administration of $50 \mathrm{mg} / \mathrm{kg}$ bw SN resulted in a $64 \%$ downregulation of the CYP2C23a gene.

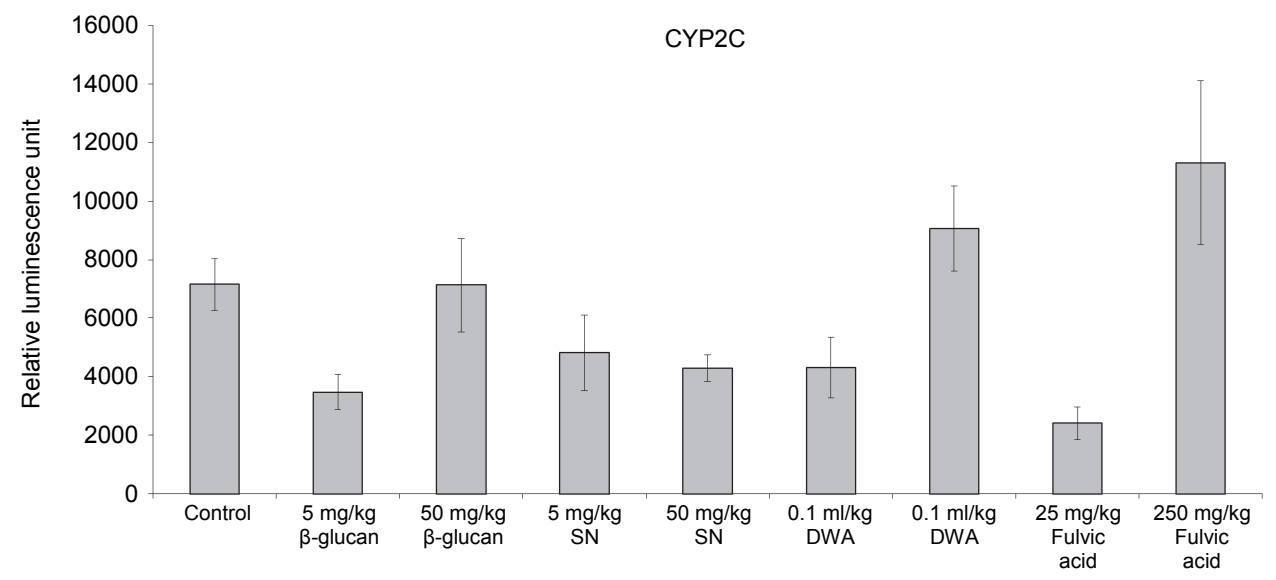

Fig. 2. Changes in cytochrome $\mathrm{P} 4502 \mathrm{C}$ enzyme activity in chicken liver microsomes ( $\mathrm{n}=5$ /group; the level of significance was set at $\mathrm{P}<0.05$; each treatment group compared to control). Data are shown as mean $\pm \mathrm{SD}$. SN - Sanguinarine-containing product, DWA - drinking water acidifier. The chickens were treated orally for 5 days

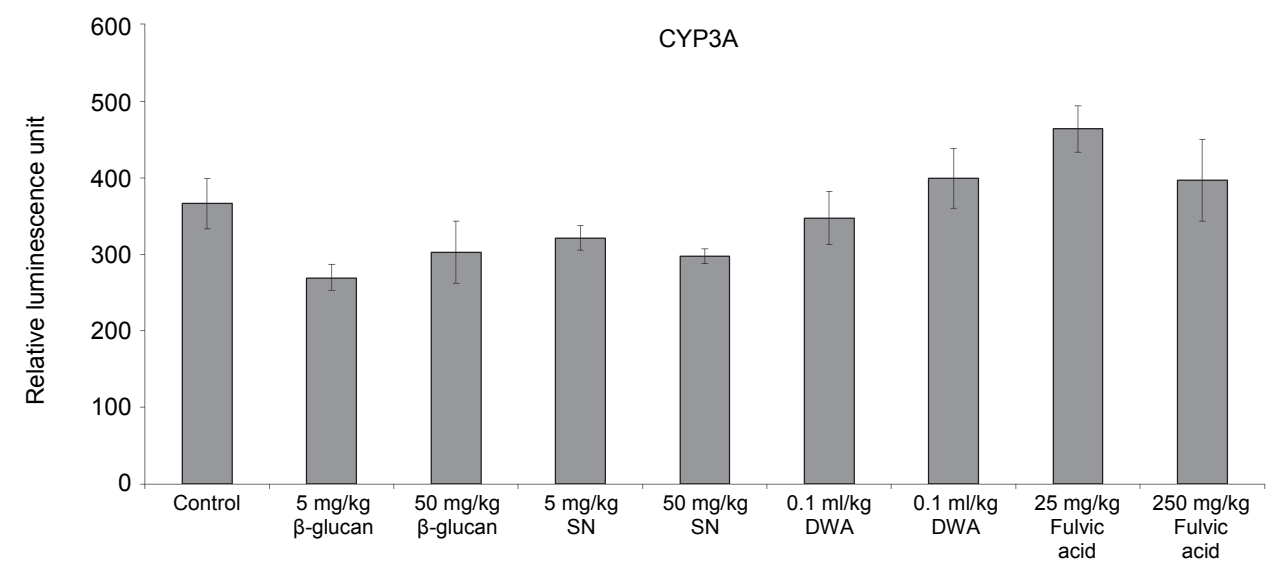

Fig. 3. Changes in cytochrome $\mathrm{P} 4503 \mathrm{~A}$ enzyme activity in chicken liver microsomes $(\mathrm{n}=5 /$ group; the level of significance was set at $\mathrm{P}<0.05$; each treatment group compared to control). Data are shown as mean $\pm \mathrm{SD}$. SN - Sanguinarine-containing product, DWA - drinking water acidifier.

The chickens were treated orally for 5 days 


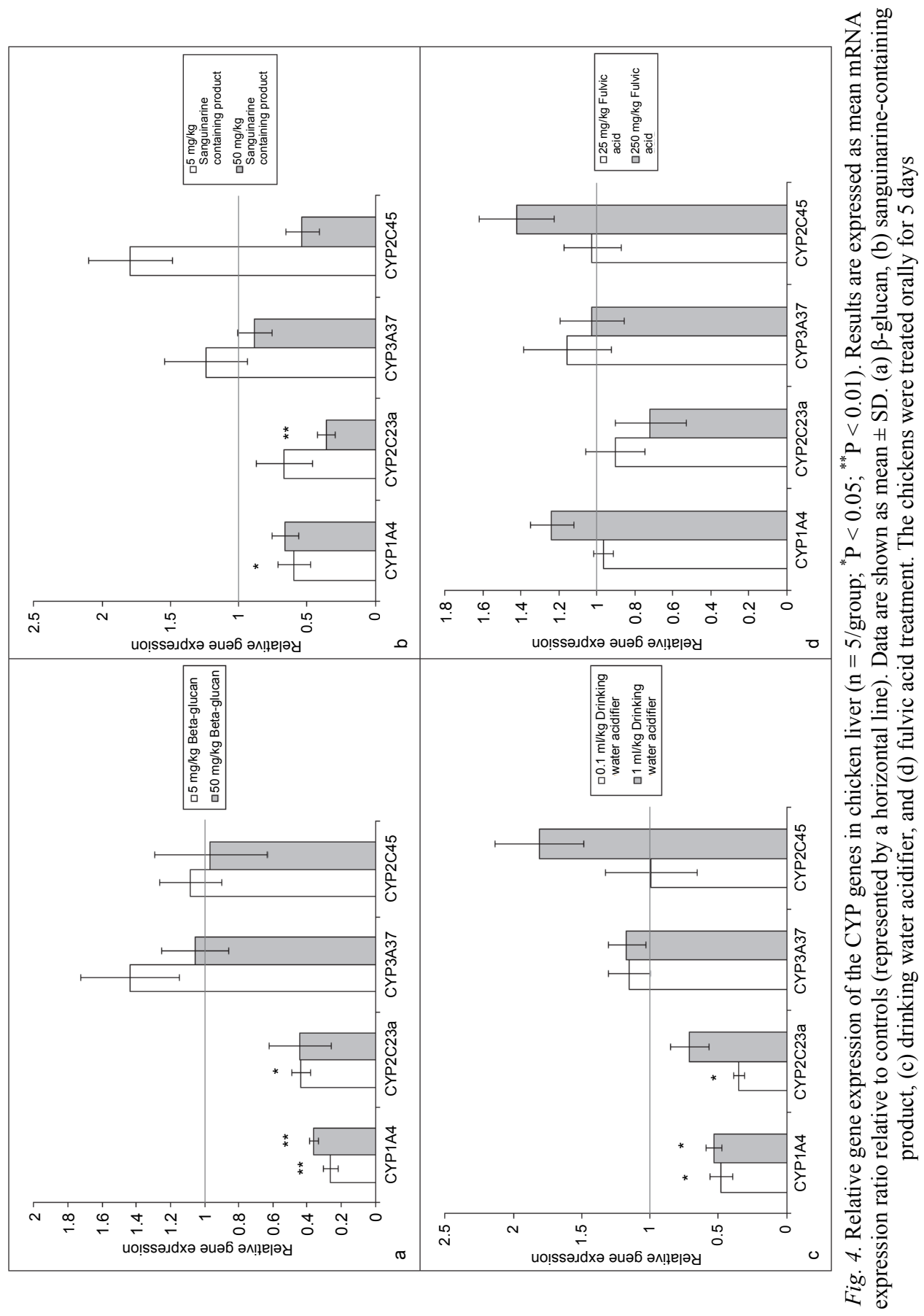

Acta Veterinaria Hungarica 67, 2019 


\section{Discussion}

In general, the administration of feed additives to chicken flocks is proven to be effective for promoting their health or weight gain during the growing period. Although they are suspected to be safe, it is presumed that orally absorbed feed additives may influence the metabolism of drugs through the enzymes of phase I and/or phase II reaction; however, few studies have defined the actual extent of these effects (Fink-Gremmels, 2008; Csikó et al., 2014; de Boer et al., 2015). The altered metabolic pattern of medicines may influence their therapeutic activity in the treated flocks and their residue levels in foods.

In this study the activity of CYP1A enzyme was enhanced after the administration of both the recommended and the tenfold dose of SN which can be explained by the fact that polycyclic aromatic substances are metabolised via this enzyme family (Sridhar et al., 2017), hence SN, a product containing quaternary benzophenanthridine alkaloids and protopine, provoked the activity of CYP1A enzymes. The other three tested feed additives increased the activity of CYP1A enzymes in the tenfold dose but not in the recommended dose, a finding that draws attention to the importance of dosing these substances in a precise manner.

There are several differences in catalytic profiles of the chicken CYP3A37 and the human and canine CYP3A enzymes. Interestingly, CYP2C23a behaves, in regard to regulation, very similarly to CYP3A37 (Ourlin et al., 2000). The chicken CYP3A37 has relatively low abundance, which suggests that this is not the most important isoenzyme in the metabolism of xenobiotics (Watanabe et al., 2013). CYP2C enzymes play major roles in the detoxification of xenobiotics (Carre et al., 2002) and their high abundance in the liver makes them the primary drug-metabolising factors. In our study, the gene expression of CYP2C23a was decreased on some occasions; however, the activity of CYP2C enzymes did not change following the administration of the four feed additives examined. Interestingly, the gene expression level of CYP1A4 was decreased after the administration of $\beta$-glucan, SN and DWA; in contrast, the same treatments increased the activity of CYP1A4. This contradiction can be the consequence of the sampling time; both the mRNA samples and the microsome samples were collected at the same time, so it is possible that the gene expression phase has been downregulated due to a feedback resulting from excess protein formation. Downregulation of the CYP2C23a gene may also be a consequence of a negative feedback as the formed CYP2C23a mRNA may inhibit the transcription of its own gene, since the activity of CYP2C remained unaltered after the treatments. Nonetheless, to prove this assumption further experiments would be necessary with more frequent sampling periods to monitor the continuity of changes in gene expression.

In conclusion, supplementation of the chickens' drinking water with $\beta$ glucan, SN, DWA or fulvic acid may cause cytochrome P450-mediated interactions, particularly with substances which are metabolised via the CYP1A en- 
zymes. This subfamily metabolises a smaller proportion of medicines and none of them are antimicrobials. Benzimidazole anthelmintic drugs have the highest possibility of interaction with feed additives on CYP1A enzymes (Diani-Moore et al., 2006) in the chicken industry, especially when certain feed additives are overdosed or supplements containing plant alkaloids are used. Care should be taken during antiparasitic therapy of the flock if the applied feed additive contains polycyclic aromatic amines such as quaternary benzophenanthridine alkaloids and protopine alkaloids.

The activity of the avian CYP2C, which is considered the most significant in avian drug metabolism, remained unchanged after the administration of each feed additive in either dose; consequently, clinically important alterations in the CYP-mediated antimicrobial metabolism have low probability. Especially the application of fulvic acid seems to be the safest with regard to possible feed-drug interactions, since neither the activity nor the gene expression of CYP2Cs was altered after five-day administration of the substance. Further investigations are needed to clarify the changes in the gene expression profile of CYP genes. Based on our results none of the treatments resulted in excess CYP2C or CYP3A protein, which reduces the emerging risk of interactions between the tested feed additives and drugs.

\section{Acknowledgements}

We are grateful to Department of Biochemistry, Eötvös Loránd University for enabling us to use their Beckman L7-65 ultracentrifuge. Part of this study was supported by the 11475-4/2016/FEKUT grant of the Hungarian Ministry of Human Resources and the European Union and co-financed by the European Social Fund (grant agreement no. EFOP-3.6.2-16-2017-00012, project title: Development of a product chain model for functional, healthy and safe foods from farm to fork based on a thematic research network, and EFOP-3.6.3-VEKOP-16-2017-00005, project title: 'Strengthening the scientific replacement by supporting the academic workshops and programs of students, developing a mentoring process').

\section{References}

Carre, W., Bourneuf, E., Douaire, M. and Diot, C. (2002): Differential expression and genetic variation of hepatic messenger RNAs from genetically lean and fat chickens. Gene 299, 235243. doi: 10.1016/S0378-1119(02)01077-6

Chang, Q., Lu, Z., He, M., Gao, R., Bai, H., Shi, B. and Shan, A. (2014): Effects of dietary supplementation of fulvic acid on lipid metabolism of finishing pigs. J. Anim. Sci. 92, 49214926. doi:https://doi.org/10.2527/jas.2014-8137

Csikó, G., Nagy, G., Mátis, G., Neogrády, Z., Kulcsár, A., Jerzsele, Á., Szekér, K. and Gálfi, P. (2014): Effects of dietary sodium butyrate on hepatic biotransformation and pharmacokinetics of erythromycin in chickens. J. Vet. Pharmacol. Ther. 37, 406-412. doi:10.1111/jvp.12109 
de Boer, A., van Hunsel, F. and Bast, A. (2015): Adverse food-drug interactions. Regul. Toxicol. Pharmacol. 73, 859-865. doi:https://doi.org/10.1016/j.yrtph.2015.10.009

Diani-Moore, S., Papachristou, F., Labitzke, E. and Rifkind, A. B. (2006): Induction of cyp1a and cyp2-mediated arachidonic acid epoxygenation and suppression of 20hydroxyeicosatetraenoic acid by imidazole derivatives including the aromatase inhibitor vorozole. Drug Metab. Dispos. 34, 1376-1385. doi:10.1124/dmd.106.009498

Fink-Gremmels, J. (2008): Implications of hepatic cytochrome P450-related biotransformation processes in veterinary sciences. Eur. J. Pharmacol. 585, 502-509. doi:10.1016/j.ejphar. 2008.03.013

Hong, Y. H., Lillehoj, H. S., Lee, S. H., Dalloul, R. A. and Lillehoj, E. P. (2006): Analysis of chicken cytokine and chemokine gene expression following Eimeria acervulina and Eimeria tenella infections. Vet. Immunol. Immunopathol. 114, 209-223. doi:http://dx.doi.org/ 10.1016/j.vetimm.2006.07.007

Islam, K. M. S., Schumacher, A. and Gropp, J. (2005): Humic acid substances in animal agriculture. Pak. J. Nutr. 4, 126-134. doi:10.3923/pjn.2005.126.134

Kantas, D., Papatsiros, V. G., Tassis, P. D., Athanasiou, L. V. and Tzika, E. D. (2015): Effect of a natural feed additive (Macleaya cordata), containing sanguinarine, on the performance and health status of weaning pigs. Anim. Sci. J. = Nihon Chikusan Gakkaihō 86, 92-98. doi:https://doi.org/10.1111/asj.12240

Nebbia, C., Ceppa, L., Dacasto, M., Nachtmann, C. and Carletti, M. (2001): Oxidative monensin metabolism and cytochrome P450 3A content and functions in liver microsomes from horses, pigs, broiler chicks, cattle and rats. J. Vet. Pharmacol. Ther. 24, 399-403. doi:10.1046/j.1365-2885.2001.00362.x

Ourlin, J. C., Baader, M., Fraser, D., Halpert, J. R. and Meyer, U. A. (2000): Cloning and functional expression of a first inducible avian cytochrome P450 of the CYP3A subfamily (CYP3A37). Arch. Biochem. Biophys. 373, 375-384. doi:10.1006/abbi.1999.1566

Palócz, O. and Csikó, G. (2014): Reduction of the excessive use of antibiotics in animal husbandry and in clinical practice. Literature review [in Hungarian, with English abstract]. Magy. Allatorvosok 136, 177-183.

Palócz, O., Farkas, O., Clayton, P. and Csikó, G. (2017): Changes in cytochrome P450 gene expression and enzyme activity induced by xenobiotics in rabbits in vivo and in vitro. World Rabbit Sci. 25, 173-180. doi:10.4995/wrs.2017.4574

Palócz, O., Szita, G. and Csikó, G. (2019): Alteration in inflammatory responses and cytochrome P450 expression of porcine jejunal cells by drinking water supplements. Mediators of Inflammation 2019, 6. doi:https://doi.org/10.1155/2019/5420381

Plaza, C., Garcia-Gil, J. C., Polo, A., Senesi, N. and Brunetti, G. (2005): Proton binding by humic and fulvic acids from pig slurry and amended soils. J. Environ. Qual. 34, 1131-1137. doi:10.2134/jeq2004.0378

Sridhar, J., Goyal, N., Liu, J. and Foroozesh, M. (2017): Review of ligand specificity factors for CYP1A subfamily enzymes from molecular modeling studies reported to-date. Molecules 22. doi: $10.3390 /$ molecules 22071143

Szabó, J., Vucskits, A. V., Berta, E., Andrásofszky, E., Bersényi, A. and Hullár, I. (2017): Effect of fulvic and humic acids on iron and manganese homeostasis in rats. Acta Vet. Hung. 65, 66-80. doi:10.1556/004.2017.007

Temesvári, M., Kóbori, L., Paulik, J., Sárváry, E., Belic, A. and Monostory, K. (2012): Estimation of drug-metabolizing capacity by cytochrome P450 genotyping and expression. J. Pharmacol. Exp. Ther. 341, 294-305. doi:10.1124/jpet.111.189597

Vieira, S., Berres, J., Reis, R., Oyarzabal, O., Coneglian, J., Freitas, D., Peña, J. and Torres, C. (2008): Studies with sanguinarine like alkaloids as feed additive in broiler diets. Rev. Bras. Cienc. Avic. 10, 67-71. 
Watanabe, K. P., Kawai, Y. K., Ikenaka, Y., Kawata, M., Ikushiro, S.-I., Sakaki, T. and Ishizuka, M. (2013): Avian cytochrome P450 (CYP) 1-3 family genes: isoforms, evolutionary relationships, and mRNA expression in chicken liver. PloS One 8, e75689. doi:10.1371/ journal.pone.0075689

This is an open-access article distributed under the terms of the Creative Commons Attribution 4.0 International License (https://creativecommons.org/licenses/by/4.0/), which permits unrestricted use, distribution, and reproduction in any medium, provided the original author and source are credited, a link to the CC License is provided, and changes - if any - are indicated. (SID_1) 